\title{
International Policies and Conventions on International Rivers and the Rights of Ethiopia to Construct Dam on Nile River: The Case of the Great Renaissance Dam of Ethiopia
}

\author{
Kassahun Mulatu Lemt Tadesse Aybera Zostiet \\ 1.Department of Natural Resource Management, Mizan-Tepi University, Mizan Teferi, Ethiopia \\ 2.School of Law, Mizan-Tepi University, Mizan Teferi, Ethiopia
}

\begin{abstract}
Sustainable transboundary water resources managements are challenged by water governance problem. Equitable and reasonable use of water resources shared by co-basin countries requires reliable common agreements. International water laws such as UN Watercourses (1997), Helsinki Rules (1966) have provided vital legal instruments for effective management and negotiation over international water courses. However, Nile River use and development has challenged for last several decades due to discriminatory bilateral agreements made during colonial periods. The Cooperative Framework Agreement (CFA) provided to achieve equitable use of Nile River and promote regional socioeconomic development is important step advancing to stop unfair water allocation and claim in the region. The enduring claim over water share and use by Egypt and Sudan referring colonial era agreements are unacceptable because they denied legal and natural rights of the upstream countries as well as opposed international water law. With this respect, Ethiopia has natural and legal right to construct Great Ethiopian Renaissance Dam. The downstream countries (Egypt and Sudan) should ratify CFA and respect international water laws. Therefore, mutually acceptable cooperative commitment amongst the riparian states of the Nile basin is the only necessary condition for promoting sustainable use and development Nile River as well as achieving peace and security in the Nile river basin.
\end{abstract}

Keywords: UN Watercourses, Helsinki Rules, Nile River basin, downstream countries, international water law principles

DOI: $10.7176 / \mathrm{IAGS} / 83-02$

Publication date: June $30^{\text {th }} 2020$

\section{Introduction}

The scarce water resource needs partnerships among countries for its sustainable use. There are about 265 transboundary water basins cover nearly $50 \%$ of the land surface supply about $60 \%$ of global freshwater flow (Paisley and Henshaw, 2013; Zhong et al., 2016). These basins are home to about $40 \%$ of the world's population (Population Reference Bureau, 2012). In Africa, transboundary water basins occupy about 62\% of landmasses (Wolf et al., 1999). Thus they link the populations both within and between countries through hydrological and economic interdependencies (United Nations-Water, 2008) and are essential in socioeconomic development (Wouters, 2013). The Nile River is considered to be the longest river in the world and home for $40 \%$ of Africans from 11 co-basin states (Obengo, 2016). It is also play the central role to the relationship between Ethiopia, Sudan and Egypt since time immemorial (Obengo, 2016). However, a skewed water control situation in favor of the downstream countries, in keeping with the colonial interests has bottleneck for their cooperation for last several (Arsano, 2007).

Ensuring social equity, economic growth and environmental and ecological protection in transboundary water basins is very crucial and challenging worldwide. The task of achieving equitable and reasonable use of water resources shared by co-basin countries need credible water governance structure (Yohannes and Yohannes 2012; Obengo, 2016) to solve disputes (Arjoon et al., 2016). However, transboundary waters have faced a variety of governance challenges (Paisley and Henshaw, 2013). These problems are ubiquitous (Rahaman, 2009) but more severe in Nile Basins, where variety of demands and water utilization interest and rights across historical periods to come amongst its co-basin states (Aslake, 2016). Different literatures suggested the need for transboundary water cooperation and agreements among the riparian countries for ensuring integrated management of the shared water resources ((Rahaman, 2009). However, intense in demands over transboundary water resource such as Nile River have escalated political, economic, and social instability in Nile river basin due to lack of common agreement, the Nile co-basin states have been moving towards constructing a regional water governance regime (Yohannes and Yohannes, 2012).

The 1997 UN IWC Convention (Zhong et al., 2016) and the Helsinki Rules on the Uses of the Waters of International Rivers and Comments of 1966 (Rahaman, 2009b) have provided a legal basis for negotiation on issues related to water courses since 1960s. The numerous other treaties and agreements regulating utilization of shared resources between states have been laid a foundation for development and codification of international water law (Mohamoda, 2003). These laws and agreements have effectively contributed positive settlement of a 
wide range of controversial issues on international water use (McCaffrey, 2007; Habtamu, 2011; Paisley and Henshaw, 2013). However, the bilateral agreements on utilization of the Nile River by colonial powers, colonial powers and regional states and between independent states of the basin (Egypt and Sudan) (Obengo, 2016) have been controversial. They excluded major Nile flow (about 85\%) contributing countries such as Ethiopia and gave a veto right to Egypt on Nile River, which contributes virtually nothing to the Nile system (Yohannes and Yohannes, 2012). Still now Egypt is insisted to continue such unfair action on Nile River to disclaim the natural and sovereign rights of upstream countries such as Ethiopia, which need to be changed.

The good supply Nile water is keystone for Ethiopia to overcome its structural poverty (Yohannes and Yohannes, 2012). The country has the natural and sovereign right to use its water resources. Thus, the government of Ethiopia has started constructing Great Ethiopian Renaissance Dam (GERD) to generate 6000 Megawatt electricity to meet demands of the country and exported to the neighboring countries (Yihdego, 2013). However, it triggered regional disagreements especially between Ethiopia and Egypt. Egypt is trying to assert its right to the lion's share of the Nile River waters validating the 1959 Nile Waters Agreements (Shay, 2017) without regards to Ethiopia. But, negotiation based on international law and respecting use rights of water producer counties such as Ethiopia is essential to strengthen 'regional hydro solidarity' that could develop traditional integrated water resources management to better include the cultural, social and political complexity of the GERD (Abdelhady et al., 2015). Therefore, aim of this paper to evaluate the use rights of Ethiopia in general and construction of GERD in accordance of international water laws.

\section{International Water Policies, Conventions and the Rights of Ethiopia on Nile River \\ 2.1 International water policies and conventions}

United Nation (UN) and bodies of UN developed the international legal instruments dealing with shared water courses: the United Nations Convention on the Law of the Non-Navigational Uses of International Watercourses of 1997(hereafter UN Watercourses Convention) and Helsinki Rules on the Uses of the Waters of International Rivers and Comments of 1966 (Rahaman, 2009b). The 2004 Berlin Rules on Water Resources is also a part these convention. These legal documents are based on theories and principles widely acknowledged by modern international water conventions, agreements and treaties therefore are important in facilitating effective transboundary water resources management and use around the world (Rahaman, 2009a).

\subsubsection{Theories and doctrines of international water law}

Theories and doctrines in water related to transboundary water resources are the basis for principles of international water laws used in the management of transboundary water resources. The theoretical foundation of the principles of international water law related to transboundary water resources management evolves mainly from four theories and doctrines: 1) theory of absolute territorial sovereignty; 2) theory of absolute territorial integrity; 3 ) theory of limited territorial sovereignty and 4) theory community of interest" of riparian states in an international water course (Rahaman, 2009a).

The theory of 'absolute territorial sovereignty: this theory argues that a state has absolute control over all waters lying within its territorial jurisdiction, and may utilize those waters without regard to its effect on other co-riparian states, especially downstream States (Daniel, 2014). With regards to Nile Basin, the upstream and downstream riparian countries have adopted variations of two conflicting and largely discredited-doctrines of international fluvial law (Azarva, 2011). According to Habtamu (2011), Ethiopia and Egypt have the least taste and inclination to this theory. However, according to Daniel (2014), historically Ethiopia has adhered to this theory, which provides that a riparian state may engage in the unrestricted use of that part of an international water course within its territory, even to the detriment of downstream parties." Though, the doctrine favors the first users such as Ethiopia to access an excessively large volume of a Nile waters, the government of Ethiopia have announced that the rate of reservoir filling and use thereafter will in a way that have no impact on stream flow to downstream.

The theory of 'absolute territorial integrity: this theory declared a state is entitled to expect that the same volume of water, uninterrupted in quantity and unimpaired in quality, flows into its territory (Oppenheim, 1955). In other words, a downstream riparian state has the right to demand the continuation of the natural flow of an international river into its own territory. This demand amounts to a restriction on the upstream riparian, which at most tolerates only minimal uses by that state and routinely favors the downstream riparian (Salman, 2007). This is actually unrealistic and difficult to implement in contemporary world where water resource is the major resources for every development and livelihoods of humankind around the world. Besides, the doctrine is not accepted by contemporary international water recourse law, it grounded in the concept of protecting existing uses (Gander, 2013). Moreover, this theory is the least policy taste particularly for Ethiopia while Egypt is cold to the theory for largely pragmatic reasons that this would scarcely fit existing international realities (Habetamu, 2011).

The theory of 'limited territorial sovereignty and integrity or intermediate theories: this theory also known as the 'theory of sovereign equality and territorial integrity'. It theory is based on the assertion that every state is free to use shared rivers flowing through its territory as long as such utilization does not prejudice the rights and interests of the co-riparian's. This indicates the sovereignty over shared water is relative and qualified. The co- 
riparian's have mutual rights and duties in the utilization of the waters of their international water course and each is entitled to an equitable share of its benefits (Rahaman, 2009a). The main source of this principle is considering the entire river basin as one economic unit and "rights over the waters of the entire river are vested in the collective body of the riparian states, or divided among them either by agreement or on the basis of proportionality (Kliot, 2005). Thus, it guarantees the right of reasonable use by the upstream countries such as Ethiopia in the framework of equitable use. Thus, Ethiopia has equal rights to use Nile River in equitable manner. As Ethiopia specified rate of reservoir filling and water use, which will not be in way to significant effect on water flow, the principle bears a duty on every riparian state to confirm their utilization is not causing significant harm to other co-riparian states. The principles of equitable and reasonable utilization and an obligation not to cause significant harm are part of this theory (Salman, 2007; Rahaman, 2009a). Though, Egypt used theory for the entire policy on Nile River for a long period of time with a set of other Conventions to satisfy its national interests (Habtamu, 2011) regardless of the assertion that every state including Ethiopia has right to freely use shared rivers flowing through its territory. The theory of a "community of interest" of riparian states in an international watercourse: this declared that a state's sovereignty is limited by similar rights of other states sharing the same basin. It emphasizes the maximum utilization and optimum economic development of an entire river basin. The theory considers the water of an international drainage basin to be managed as a unit without regard to national territorial boundaries. It also advised that various riparian states should manage and develop the drainage basin jointly and share the benefits derived there from (Habtamu, 2011). Though, this theory has never been widely accepted and applied by Egyptian, especially with regard to the non-navigational uses of international water courses, like GERD. But the theory attracts Ethiopia more than Egypt as a basis of general principle and policy toward the utilization of the waters of the Nile River (Habtamu, 2011). In this regards, Egypt have no legal foundation to oppose the GERD and water use thereafter as long as the water use by Ethiopia obey this theory. Generally, except the theory of 'absolute territorial integrity', which was rejected by contemporary international water recourse law, all the theories supports Ethiopia to use its water curses including construction of GERD.

\subsubsection{Principles of international water law}

The principles of international water law on transboundary water courses are very important to facilitate effective governance and sustainable development in the basins. Regarding this the Helsinki Rules (1966) and the UN Watercourses Convention (1997) can be worth mentioned. However, some principles are not acceptable globally and applicable to transboundary water resources management and unified in modern international conventions, agreements and treaties. For instance, among the key principles (Article 5 to Article 10) of UN Watercourses Convention (1997), the equitable and reasonable utilization and participation (Article 5) and an obligation not to cause significant harm (Article 7) are essential to the convention. Accordingly, the key principles under Helsinki Rules (1966) and UN Watercourses Convention (1997), which are relevant Articles of some of the modern international water conventions and endorsed in treaties and agreements are summarized into four (Table 1)(Rahaman, 2009b). Besides, they are core to the governance of Nile river basin as well as settlement of disputes over construction of GERD.

Table 1.Transboundary water management principles and relevant Articles of international conventions, agreements/ treaties.

\begin{tabular}{|c|c|c|}
\hline Principles & Helsinki Rules (1966) & UN Watercourses Convention (1997) \\
\hline 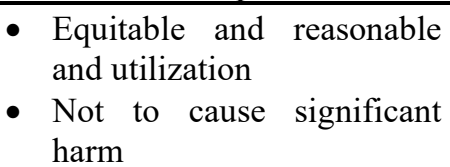 & Articles $4,5,7,10,29$ (4) & $\begin{array}{l}\text { Articles } 5,6,7,15,16,17,19 \\
\text { Articles 7, 10, 12, 15, 16, 17, 19, 20, 21(2), } \\
22,26(2), 27,28(1), 28(3) \text { (Articles 3, 7, 8) }\end{array}$ \\
\hline $\begin{array}{l}\text { - } \begin{array}{l}\text { Cooperation and } \\
\text { information exchange } \\
\text { - Peaceful settlement } \\
\text { of disputes }\end{array} \\
\end{array}$ & $\begin{array}{l}\text { Articles } 29(1), 29(2), 31 \\
\text { Articles } 26 \text { to } 37\end{array}$ & $\begin{array}{l}\text { Articles } 5(2), 8,9,11,12,24(1), 25(1), 27 \text {, } \\
28(3), 30 \\
\text { Article } 33\end{array}$ \\
\hline
\end{tabular}

Adapted from Rahaman, 2009b

The equitable and reasonable use principle:

The principle of equitable and reasonable utilization by both upstream and downstream countries of an international river, as enshrined in Article 5 (1) of the UN Watercourses Convention (1997) deemed as codifications of most, if not all, relevant customary principles (Margaret, 2012). However, Egypt argue that as a desert nation it has no other option for survival except Nile River, though upstream countries have other water resource option including heavy rainfall for agricultural needs. But Ethiopia and other riparian countries base their argument on the equitable use and utilization principle, which is regarded by many as part of customary international law (Yihdego, 2013). However, Egypt argues international law to support its claim that it has a near exclusive right to use the Nile and its resources by providing different justification by citing that of colonial period 
treaty. For instance, Egypt would argue that a 1902 treaty between Great Britain and Ethiopia of Article III of the Treaty in which Ethiopia purports to disclaim any right to the Nile and agrees not to take any measures that would reduce the availability of the Nile's water resources to Egypt, precludes GERD Project (Daniel, 2014).

Besides, Egypt has argued that 1929 and 1959 treaties between Egypt and Sudan purporting to govern the use of the Nile though these states were not formal parties to the agreements. Egypt also tried to rely on Article 7 of the 1997 UN Convention, which imposes a duty on states to take measures to prevent causing significant harms to other states sharing an international watercourse, to argue that it has a right to limit upper riparian development of the Nile's water resources. This to claim the Dam project will cause significant harm to Egypt by negatively affecting the Nile's water volume and reducing Egypt's water resources (Daniel, 2014). However, Ethiopia is one of the signatories to Nile Basin Cooperative Framework Agreement (CFA), formulated to achieve sustainable socio-economic development through the equitable utilization of, and benefits from, the common Nile Basin water resources'. Besides, the Nile Basin Initiative (NBI) has provided a convenient forum for the negotiation of a Cooperative Framework Agreement (CFA) to set up a permanent, inclusive legal and institutional framework (Mekonnen, 2010). But still Egypt has not signed the agreement and becoming the part of solution for unabated disputes over the Nile River in the region. The claim of inherent and existing use as a bar for the equitable and reasonable use has been expressly rejected in the 1997 UN Convention (Yihdego, 2013). Ethiopia also rejected the validity of the 1902 treaty with Great Britain and argues that Article 5 of the Convention and the Harmon Doctrine support its decision to utilize the Nile's water resources and develop the Dam Project (Daniel, 2014).

\section{The obligation not to cause significant harm principle:}

The states in an international drainage basin are allowed to use the water courses in their territory in a way that would not cause significant harm to other basin states or to their environment, including harm to human health or safety, to the use of the waters for beneficial purposes or to the living organisms of the watercourse systems (Rahaman, 2009a; 2009b). The state ought to 'take all appropriate measures', in consultation with concerned parties, to prevent such significant harm, for example, denying water necessary for human survival, by an upstream county, may well amount to causing a significant harm (Schrijver and Weiss, 2004).

As aforementioned, Egypt could rely on this principle as imposes a duty on states to take measures to prevent causing significant harms. Therefore, whether the GERD will inflict a significant harm on Egypt and Sudan, Ethiopian initiated tripartite Technical Commission mandated to examine the potential impacts of the dam on downstream countries, submitted its report to all concerned on $1^{\text {st }}$ June 2013. Moreover, Ethiopia also confirms that the dam will not have a significant negative impact on either Egypt or Sudan and meets international water laws and standards. But Egypt has less likely convinced as they fully reliant on the inherent absolute use principle. To its extremes, Egypt expressed its national interests rather than regional right regardless of the water laws. The duty to prevent and avoid a significant harm means it does not preclude utilization of a river by upstream in an equitable and a reasonable manner rather preventing a significant harm is only meant to ensure, for example, that 'minimum individual water requirements' of human beings, in downstream countries, is not significantly affected (Yihdego, 2013).

In addition to referring 1902 treaty, Egypt also likely subscribes to the appropriation doctrine of allocating water rights, linked to a theory of prior or historical use by ignoring other versions of the appropriation doctrine, it basically stands for the proposition that the first user of some amount of water for a beneficial purpose has an exclusive property right to the amount of water utilized as against subsequent users (Daniel, 2014). However, such notion has denied the realities and legally acceptable.

\section{The principles of notification, consultation and negotiation:}

Every riparian state in an international water course is entitled to prior notice, consultation and negotiation in cases where the proposed use by another riparian of a shared water course may cause serious harm to its rights or interest. However, naturally, most upstream countries often oppose this principle, for example Ethiopia and Rwanda in Nile basin (Karkkainen, 2005). This could be due to the nature of downstream countries who always deny the natural and legal use rights for past several centuries. Though, concerning GERD dam, Ethiopia is tolerant the need to conduct further studies on some aspects of the project, insists that not only will the flow of water not be reduced, but also the dam will benefit riparian countries(Yihdego, 2013).

\section{The peaceful settlement of disputes principle:}

This advocates all states in an international water course should seek a settlement of the disputes by peaceful means, in case states concerned cannot reach agreement by negotiation (Karkkainen, 2005). As both countries are members of the African Union, article 4 of the Constitutive Act of the Union prohibits 'the use of force or threat to use force among Member States' and interference upon a member State's internal affairs. However, different media sources showered Egypt used different option to stop the construction of the GERD. But this could not be a solution for the regions. Rather Egypt should act according to all laws and principles and thereby can maintain its share. 


\subsection{Nile River Treaties and Legal Claims of Ethiopia}

The Nile River is subject to the international law of Transboundary Rivers primarily regulated by treaty law between interested parties. Currently, there are two main disputes between Egypt and other Nile basin countries: the distribution of the Nile water and the construction of GERD on the Blue Nile in Ethiopia (Shay, 2017). Particularly, the tension between Egypt and Ethiopia has increased owing to ongoing construction of the GERD on Blue Nile River (Veilleux, 2015). Though, Egypt is sometimes the sole significant user of Nile water virtually all of its surface water flows comes entirely from outside of its borders (Whittington et al., 2014).

The important treaty made on Nile river that influence the current use of the water are the colonial Tripartite Treaty 1906 among Britain, France, and Italy, followed by the treaty between Egypt and Anglo-Egyptian Sudan of 1929 and the 1959 treaty between Egypt and Sudan which reinforced the 1929 Nile Water Treaty. The above all agreement denied the use rights of the upstream countries such as Ethiopia. These treaties are often referenced by Egypt to keep their national interests although Ethiopia reflects these treaties invalid, as they unjustly exclude Ethiopia, which contributing about $85 \%$ of the River's waters. The 1929 treaty, which allocates $90 \%$ water use of the Nile River for several decades by Egypt and Sudan, on the basis of their colonial rights of Britain may be said to become a local custom and challenge them. Moreover, Colonial Britain signed unilateral agreements to protect its interests with upstream countries, a fact which may well reinforce the above treaty. However, Ethiopia did not only refuse to consent to the treaties but also strongly and persistently rejected their legality from the outset (Yihdego, 2013).

The most contentious Nile agreement in history is the agreement signed between colonial Britain and Ethiopia on May 15, 1902. The Article III of the Treaty stipulated: Not to construct or allow to be constructed any work across the Blue Bile, Lake Tana, or the Sobat, which would arrest the flow of their waters except in agreement with His Britannic Majesty's Government and the Government of Sudan" (Okoth-Owiro, 2004; Yihdego, 2013). The treaty has mistranslation between the English and Amharic versions of the treaty when signed by Emperor Menelik. According to the Amharic version, 'arrest' had been translated into 'stop', that is, as long as Menilek did not stop the waters the agreement did not prevent him from utilizing and diverting Blue Nile water. Thus, Ethiopia has ever since rejected this agreement - calling it "illegitimate" (Yihdego, 2013). Such error of a 'fact or situation' rendered the treaty as void, as per Article 48 of the Vienna Convention on the Law of Treaties (VCLT) 1969 which mostly codified customary treaty rules. The Treaty was also never ratified by Ethiopia. Arguably, Ethiopia and other upstream countries are bound by the colonial treaties, especially the 1929 and 1959 Treaties concluded between Egypt and Sudan. According to Article 34 of the VCLT the treaty cannot create either obligations or rights for a third Sate without the consent of Ethiopia. Moreover, the Treaties must not invade the legal entitlements of Ethiopia and other upstream countries without their expressed will.

Generally, Nile basin agreements before the 1959 were either between colonial powers in the region or between Sudan and Egypt (downstream countries); none of the upper riparian countries were part of them. From the point an international law perspective, those agreements are incomplete, contentious and fragmented treaty regimes (Aslake, 2016). Therefore, the post-colonial independence countries in the Nile Basin rejected the discriminatory treaty regimes (Yihdego, 2013). However, recently the Nile basin countries formed a framework to reverse the colonial discriminatory rule in the Nile Basin. This was the practical steps to create a new regime as evidenced by the 1999 Nile River Initiative (Yihdego, 2013). The Nile Basin Initiative (NBI) which was launched in February 2009 serves as a collaboration between the Nile riparian countries that "seeks to develop the River in a cooperative manner, share substantial socioeconomic benefits, and promote regional peace and security" (Mekonnen, 2010; Yihdego et al., 2017) but also make an effort towards establishing a legal and institutional frameworks. Such institution can improve coordination, collaboration and mitigating conflicts among parties via data and information generation for the shared water resource (Eckstein, 2009) and helping resource users to handle rapidly changing physical or political conditions' (Berardo and Gerlak, 2012).

All the affected countries of upstream put forward proposal for "equitable shares" to achieve sustainable socio-economic development through the equitable and reasonable utilization of and benefit from the common Nile basin water resources (Yacob, 2004; Dereje, 2010; Shay, 2017). After 10 years of negotiations, the Entebbe Agreement or 'Cooperative Framework Agreement(CFA)' was signed in 2010 by six Nile Basin countries: Ethiopia, Kenya, Rwanda, Tanzania, Uganda and Burundi, and also reversed British-colonial-era agreements dating back to 1929 and allows them to work on river projects without Cairo's prior agreement. After two years, the Republic of South Sudan also signed the accord becoming the seventh country to join the agreement on the Nile River basin. But, the Cooperative Framework Agreement (CFA) has not been signed by Sudan and Egypt (Shay, 2017) as they wish to retain veto powers over upstream developments. Both countries claim that the accord violates the 1959 treaty which gives Sudan and Egypt exclusive rights to the water of the Nile (Yihdego et al., 2017). Due to this, the initiative did not solve the conflict between Egypt and Sudan's claims of historic rights sanctioned by 1959 Treaty, and the upper river states' claims for equitable shares (Shay, 2017). 


\section{Summary and Future Prospect}

\subsection{Summary}

Transboundary water resources such as Nile River management has challenged by deficiency of agreed conventions among riparian countries and reliable water governance structure. This cause hydro political tension between Nile Basins especially Ethiopia and downstream countries (Egypt and Sudan). However, UN Watercourses (1997) and Helsinki Rules (1966) provide the important legal instruments for effective management and settlement on disputes in international water courses. They are globally supported by different water laws. However, some bilateral agreements made over Nile River during colonial periods are obstacle to their proper implementation and solving disputes in the regions.

The bilateral agreement during colonial periods prevents poor country such as Ethiopia not to use their transboundary water according to international law to resolve chronic poverty. However, numerous theories and principles of international water laws supported equitable and reasonable use rights of upstream countries such as Ethiopia like GERD construction. In this regard, the 'absolute territorial sovereignty', 'limited territorial sovereignty and integrity 'and theory of a "community of interest" of riparian states supported Ethiopia to use its water rationally. The basic principles of UN Watercourses (1997) and Helsinki Rules (1966), which of are supported by current convention and agreements laid on the equitable and reasonable utilization principle, the obligation not to cause significant harm principle, principles of information and notification, prior consultation and negotiation and the peaceful settlement of disputes principle which are also accepted as an international customs supported Ethiopia. However, Ethiopia opposes some of the principle that precludes its sovereign right on its natural resource use. Though, the country initiated tripartite Technical Commission mandated to examine the potential impacts of GERD on downstream countries and also tolerant to the need to conduct further studies on some aspects of the GERD project showed how the respected the above principles, laws and rights of other countries. The Cooperative Framework Agreement (CFA) provided by NBI also created a convenient forum for the negotiation over Nile River use and signed eight upstream countries except Sudan and Egypt. The CFA have an objective to use the resource equitable and promote regional socioeconomic development as well as to over turned British-colonial-era agreements. Though, the bilateral agreements of 1902, 1929 and 1959 continue to be regarded as acceptable or justifiable legal documents by downstream states (Egypt and Sudan) for discussion over Nile River, though Ethiopia and other upstream countries strongly condemned their legality.

Generally, from international transboundary water principles and laws point of views it can be concluded that most of the theories and principles of international water laws were supported the use rights of upstream countries in general and construction of GERD in particular. On other hand, downstream countries, specifically Egypt and Sudan have to obey these principles and laws used by international community. Intensifying contemporary hydro politics by claiming those discriminatory treaties will not deliver any peaceful and sustainable water use and development of the regions. Therefore, countries should act according to CFA.

\subsection{Future Prospect}

International water course links different parts of the globe as well as the region of Nile Basin. Moreover, the increase in water scarcity in future due to the increasing gap between water demands and supply is expected and needs cooperation among countries. Thus:

* It is crucial to avoid dispute and conflicts over water distribution and come to collaboration on the bases of international customs

\# Downstream countries like Egypt and Sudan should respect the legal as well as natural rights of the upstream countries.

* The upstream countries should work together to bring Egypt and Sudan to the negotiating around table, and perhaps sign the Cooperative Framework Agreement (CFA) of Nile initiative (NBI).

* Collaboration and political negotiation on Nile River is inevitable solution to settle tension in the region in general to promote sustainable and reasonable use the Nile River,

* The upstream states will also have to make equally sure that all participating countries are willing to adopt and implement the best possible systems of water use, management and protection,

* Egypt and Sudan sooner or later sign and ratify the Cooperative Framework Agreement instrument and cooperate with the upstream countries in establishing the Nile River Basin Commission. As long as the CFA manages to provide water security for all the Nile riparian countries, Egypt and Sudan will have no sound or justifiable reasons for abstaining from negotiating with the other participating countries about all aspects of the water use. Besides, maintaining the water status quo and to monopolize the water resources that originate in countries beyond their territorial jurisdiction will no longer sustainable and beneficial.

$\$$ Finally, whatever the case may be, mutually acceptable cooperative commitment amongst the riparian states of the Nile basin is an indispensable condition for inspiring sustainable development in all the countries concerned and for ultimately achieving that state of peace and security among the riparian stats 
that has for so long been a precondition for the improvement and advancement of the whole region.

\section{Reference}

Abdalla A. Ahmed4 and Ahmed K. Eldaw. 2002. Challenges and Future Opportunities in The Nile Basin. In: Castelein S. (ed.). From Conflict to Co-operation in International Water Resources Management: Challenges and Opportunities. Proceedings.

Arjoon D., TilmantA.andHerrmann M. 2016. Sharing water and benefits in transboundary river basins. Hydrol. Earth Syst. Sci. 20:2135-2150.

Aslake, E. N. 2016. Construction of Grand Ethiopian Renaissance Dam on the Nile: Cause for Cooperation or Conflict among Egypt, Ethiopia and Sudan. Thesis submitted to University of Tampere School of Social Sciences and Humanities Master's Degree Program in Peace, Mediation and Conflict Research (Peace and Conflict Research).

Awulachew S.B., Smakhtin V., Molden D., Peden, D, 2012. The Nile River Basin: Water, Agriculture, Governance and Livelihoods. Routledge, London, p. 250.

Azarva J D.2011.Conflict On The Nile: International Watercourse Law And The Elusive Effort To Create A Transboundary Water Regime In The Nile Basin. Temple Int'l \& Comp. L.J.

Daniel A. 2014."Egypt, Ethiopia, and the Nile: The Economics of International Water Law," University of Chicago Public Law \& Legal Theory Working Paper, No. 484.

Dellapenna W. Joseph.1996. "Rivers as Legal Structures: The Examples of the Jordan and the Nile." Natural Resources Journal. 36: 217-250.

Dereje Z .M. 2010.The Nile Basin Cooperative Framework Agreement Negotiations and the Adoption of a 'Water Security 'Paradigm: Flight into Obscurity or a Logical Cul-de-sac? The European Journal of International Law. 21 (2): 421-440.

Gander M.J., 2013.The role of international water law and supporting universally applicable water management principles in the development of a model transboundary agreement between riparians in international river basins. Washington State University.

Habtamu A.2011. International Legal Perspectives on the Utilization of Trans-Boundary Rivers: The Case of the Ethiopian Renaissance (Nile) Dam. Paper Presented to the Ninth IUCN Colloquium, North West University of South Africa, Eastern Cape

Hammond M. 2013. The Grand Ethiopian Renaissance Dam and the Blue Nile: Implications for transboundary water governance. Discussion Paper 1307.

Karkkainen B.C.2005. Transboundary ecosystem governance: Beyond sovereignty. Public participation in the governance of international freshwater resources.72-87.

Kliot N.2005. Water resources and conflict in the Middle East. New York: Routledge.

Lautze J. and Giordano M., 2005. Transboundary water law in Africa: Development, nature, and geography. Natural Resources Journal.1053-1087.

Margaret J. V. 2012. 'The Law of International Waters: Reasonable Utilization' Chicago-Kent Journal of International and Comparative Law.121.

Mohamoda D.H. 2003. Nile Basin cooperative: Literature review. Current African issue, No 6

Okoth-Owiro A. 2004. The Nile Treaty-State Succession and International Treaty Commitments: A Case Study of the Nile Water Treaties. Occasional paper, East Africa 9.

Paisley R.K. and Henshaw T.W., 2013. Transboundary governance of the Nile River Basin: Past, present and future. Environmental Development.( 7):59-71.

Paisley, R.K. 2004. International water law, transboundary water resources and development aid effectiveness. Indian Jurisdiction Review.1: 67. McCaffrey, S.C. 2007. The Law of International Watercourses, $2^{\text {nd }}$ ed. Oxford University Press, Toronto.

Rahaman M.M. 2009b. Principles of Transboundary Water Resources Management and Ganges Treaties: An Analysis. Water Resources Development. 25(1): 159-173.

Rahaman, M.M.2009a. "Principles of international water law: creating effective transboundary water resources management." International Journal of Sustainable Society 1(3): 207-223.

Salman S.M. 2007. The United Nations Watercourses Convention ten years later: Why has its entry into force proven difficult? Water International.32(1):1-15.

Schrijver N.J. and Weiss F. (eds.). 2004. International law and sustainable development: principles and practice.Vol. 51.MartinusNijhoff Publishers.

Shay S. 2017. Between the "Entebbe agreement" and Entebbe meeting" $<$ http://www.herzliyaconference.org/_Uploads/dbsAttachedFiles/NileBasinShaulShay_100617.pdf> [Accessed on January 1, 2018]

VeilleuxJ.C . 2015. Water Conflict Case Study - Ethiopia's Grand Renaissance Dam: Turning from Conflict to Cooperation. Reference Module in Earth Systems and Environmental Sciences. 
Whittington D., Waterbury J. and Jeuland M.2014. The Grand Renaissance Dam and Prospects for Cooperation on the Eastern Nile.

Wolf A.T., Natharius J.A., Danielson J.J., Ward B.S. and Pender J.K. 1999. International river basins of the world.International Journal of Water Resources Development, 15(4): 387-427.

Wouters P. 2013.International Law - Facilitating Transboundary Water Cooperation.TEC Background Papers No. 17

Yacob A. 2004. Ethiopia and the Nile: Dilemmas of National and Regional Hydropolitics. Thesis presented to the Faculty of Arts of the University of Zurich for the degree of Doctor of Philosophy.

Yihdego Y., Khalil A. and Salem H.S. 2017. Nile River's Basin Dispute: Perspectives of the Grand Ethiopian Renaissance Dam (GERD). Global Journal of Human-Social Science (B).17(2)(1).

Yihdego Z. 2013.The Blue Nile dam controversy in the eyes of international law.Discussion Paper 1326.

ZhongY., Tian ., Hu H., Grey D. and Gilmont M. 2016. Rivers and reciprocity: perceptions and policy on international watercourses. Water Policy. 18: 803-825.

Obengo, J.O. 2016. Hydropolitics of the Nile: The case of Ethiopia and Egypt, African Security Review, DOI: 10.1080/10246029.2015.1126527

Mekonnen D Z. 2010. The Nile Basin Cooperative Framework Agreement Negotiations and the Adoption of a 'Water Security' Paradigm: Flight into Obscurity or a Logical Cul-de-sac? The European Journal of International Law. 21( 2): 421-440. 